\title{
ANALYSIS OF THE COMPLETENESS OF INDICATORS OF SOIL ASSESSMENT IN UKRAINE BASED ON MATERIALS OF THE INSTITUTE OF LAND MANAGEMENT OF THE UAAS
}

Patiyuk $\boldsymbol{O}$., postgraduate student.

Institute of Land Management of the National Academy of Agrarian Sciences of Ukraine, e-mail: o.patiyuk@gmail.com

Annotation. Taking into account the fact that the soil appraisal data is the basis for the economic valuation of agricultural land, and the data on the economic valuation of land is the basis for the normative monetary valuation of land plots, that is, there is a single, continuous methodological process of land valuation in which the data are unreliable in the first stage generates calculation errors in the following stages.

Since the issue of soil appraisal in the conditions of market land relations does not lose its relevance, and taking into account that the last time work on soil appraisal of agricultural lands in Ukraine was carried out in 1993, and over the past quarter century, formally, should already be carried out, at least three new soil appraisal tours, as it is prescribed in the Law of Ukraine "On land valuation", but in fact, the soil appraisal indicators were not updated for various reasons.

The authors analyzed the database of soil assessment in Ukraine according to 1993 scales, as well as the explications of agro-industrial groups of soils of natural agricultural regions (NAR) for the stock materials of the Institute of Land Management of the UAAS, on the basis of which an attempt was made to determine the completeness of the soil cover of the NAR of Ukraine for the indicators of assessment .

The study shows that the indicators of soil appraisal on the materials of the Institute of Land Management of the UAAS in their completeness far from always 
can serve as the basis for a continuous monetary assessment of agricultural land and require research using new approaches and developments.

Key words: soil bonitet, economic assessment of agricultural production groups of soils, soil assessment, agricultural land.

Problem statement. "The main natural wealth of the country are soils, and their study is a national matter" V.V. Dokuchaev.

The first information about the quality of the soils of ancient Russia, their socalled appraisal, we find among the farmers. Farmers considered the earth to be the mother of all their riches; they constantly studied it as the main condition for their existence. "Earth is the nurse" - this is what the Slavs called it. Although the farmer of those times was not armed with scientific data on the chemical composition and physical properties of the soils he cultivated, he knew from everyday experience that soils that were different in their external attributes - in color, composition, and features of their processing — also had different fertility, produced a kind of assessment of soils by their production efficiency. The farmers put black and dark gray soils in the first place, since they considered them to be the best, and light gray and white soils were infertile. Farmers were the first to conduct something like a soil assessment of the soils of ancient Russia.

The issue of land appraisal in the conditions of market land relations does not lose its relevance, because, considering that the last time work on appraisal of agricultural land soils in Ukraine was carried out in 1993, and the Law of Ukraine “On Land Assessment" requires appropriate land appraisal at least every 7 years [1], then more than in the last quarter of a century, formally, at least three new soil assessment tours should already be held. In fact, the soil appraisal indicators, for various reasons, were not updated, therefore, an important scientific task is to analyze the suitability and completeness of the appraisal indicators for use in other land appraisal works, because they are taken into account in the basis of normative and expert monetary valuation of land plots.

Analysis of recent scientific publications. The issue of soil appraisal is highlighted in the works of such scientists as A.P. Kashana, V.V. Medvedev, V.V. 
Plisko, I.V., Sery, D.S. Bulgakov I.S. Tan, A.V. Tichenko, D.R. Sanahatullina [12], V.A. Makht, V.A, Rudi [13].

The purpose of the article is to analyze the completeness of indicators of soil assessment in Ukraine based on materials, as the basis for a monetary assessment of agricultural land.

Statement of the main material. The founder of soil assessment is V. Dokuchaev, who divided the land appraisal work into 2 parts. The first of them is natural-historical, which in the modern sense means "soil assessment" and economic and economic "economic assessment of the land." Dokuchaev's main principle of evaluation was the need to maintain a close relationship between these components, that is, the natural-historical part should be the basis and criterion for economic.

According to I.V. Plisko, the method of V.V. Dokuchaev was far ahead of his time. Soil assessment was based on soil properties, not economic indicators derived from them (yield and income), as happened, for example, in Ukraine in the eighties of the last century, a wide range of soil properties were used, including physical soil parameters, which was not practically in any of the following methods, with the exception of the method used in France[9].

A.P. Kanash noted that soil appraisal can be considered as a specialized classification of soil according to its natural properties, characterizing their fertility in relation to various crops and reflects the degree to which the soil corresponds to the biological needs of specific crops[11].

Soil assessment of the Ukrainian SSR was carried out in most areas according to the methodology developed by the Ukrainian Research Institute of Soil Science and Agrochemistry. A.N. Sokolovsky. A distinctive feature of this method is that the subject of the assessment is not the soil variety, as was accepted by most soil scientists, but the agricultural production group and soil subgroups, and the evaluation criterion is the yield[3].

The current stage of soil scoring in Ukraine begins according to the method of V.P. Kuzmichev, who received comparative assessments of soil productivity, using 
as the main criterion the long-term productivity of leading crops on collective farms and state farms of the country. Information was collected on 100 thousand households over 20 years. To separate the influence of soils from other factors, agricultural zoning has been proposed. As a result of these works, 101 districts with the same type of soil, climate, specialization of farms, and a similar level of production resources (provision with labor, machinery, fertilizers) were allocated. Within the districts of the economy were combined into groups. The spatial unit of valuation was actually an agricultural production group and the soil type prevailed in it. Several rating scales have been drawn up for the general bonitet for yield and gross yield per 1 ha of arable land for the main products of grain and industrial crops (in grain units) and partial bonitet for the yield of individual crops. On the basis of the soil map of Ukraine on a scale of 1: 1,500,000, maps of soil tolerance were constructed according to the degree of their suitability for growing various crops, and a unified scale (classification) of a qualitative assessment of Ukrainian soils[4].

The very need for information on comparative assessments of soil quality arose as far back as the 90s of the last century before conducting an economic assessment of land. Soil appraisal of agricultural land in Ukraine was carried out in accordance with the "Method of soil appraisal of Ukraine", which, according to A. Tichenko, was the most acceptable at that time [10]. This methodology was reviewed and approved at a meeting of the Agriculture Department of the Ukrainian Academy of Agrarian Sciences on 03.03.1992 (protocol No. 2) and "Methodological recommendations for soil assessment", which were reviewed and approved by the scientific and methodological council on soil assessment in Ukraine on 01.21.1993. The object of the valuation was accepted units of soil cover that were highlighted on soil maps and combined into agro-industrial soil groups in accordance with the "nomenclature list of agro-industrial soil groups of the Ukrainian SSR" (K., 1978). Despite the fact that valuation indicators give a comparative assessment of the natural characteristics of soils - their fertility, they can be used as an objective basis for differentiating normative rental income[5]. 
Soil appraisal indicators are used:

- according to Art. 37 of the Law of Ukraine "On Land Management" - the data of soil appraisal are used in the implementation of land management with the aim of developing a set of measures for land management regarding the use and protection of land, the preservation and improvement of soil fertility [6];

- according to the Resolution of the Cabinet of Ministers of Ukraine "On expert monetary valuation of land plots" - when comparing the sale prices of similar land plots under agricultural land, among other factors, the qualitative characteristics of land plots, such as fertility and soil condition (bonitet), are taken into account [7];

- according to the Decree of the Cabinet of Ministers of Ukraine "On the Size and Procedure for Determining the Losses of Agricultural and Forestry Production Subject to Compensation" - determining the losses of agricultural production caused by the removal of agricultural land (arable land, perennial plantations, hayfields, pastures) for use for purposes not related to farming - agricultural land plot bonus value is withdrawn, as well as agricultural land bonus rating in the Autonomous Republic of Crimea, in BLAST, cities Kiev and Sevastopol[8].

Extensive experience in assessing soils in the countries of Eastern Europe, Poland, Bulgaria, the former East Germany, etc. As a rule, these works are in many respects similar to the works that were carried out in our country. In their studies, East European researchers relied on the experience of the USSR.

The valuation and economic assessment of soils in Poland is carried out by the Ministry of Agriculture, where the land is divided into 6 classes from best to worst land.

The soil classification in the GDR was based on the classification of the wellknown gnosis G. Strem, where 227 classes of arable land were identified.

In the USA, land assessment is carried out in two aspects: arable land, meadows and pastures, and forest. The basis for the assessment of soils are the following materials such as soil maps compiled on the basis of scoring, data on crop yields on various soils, Mitsa location, etc. The most common methodology 
for soil assessment in the United States is the methodology developed by the Soil Protection Service [14].

Based on the foregoing, we analyzed the database of soil assessment of Ukraine on the scales of 1993, as well as the explications of agricultural groups of soils of natural agricultural regions (NAR) based on the materials of the Institute of Land Management of the UAAS, on the basis of which an attempt was made to determine the completeness of the soil cover of the PSGR of Ukraine scoring indicators.

As a result of the study, a table was compiled, which reflects the weighted average indicators of completeness of coverage of indicators of appraisal of agricultural groups of soils by regions of Ukraine

Table 1 - the completeness of indicators of soil appraisal of agricultural land by regions of Ukraine

\begin{tabular}{|c|c|c|c|c|c|c|c|c|}
\hline & \multicolumn{2}{|c|}{ arable land } & \multicolumn{2}{|c|}{ perennial plantings } & \multicolumn{2}{|c|}{ hayfields } & \multicolumn{2}{|c|}{ pastures } \\
\hline region & $\begin{array}{l}\text { coverage of } \\
\text { agricultural } \\
\text { groups, \% }\end{array}$ & $\begin{array}{c}\text { area } \\
\text { coverage, } \\
\%\end{array}$ & $\begin{array}{c}\text { coverage of } \\
\text { agricultural } \\
\text { groups, \% }\end{array}$ & $\begin{array}{c}\text { area } \\
\text { coverage, } \\
\%\end{array}$ & $\begin{array}{l}\text { coverage of } \\
\text { agricultural } \\
\text { groups, \% }\end{array}$ & $\begin{array}{c}\text { area } \\
\text { coverage, } \\
\%\end{array}$ & $\begin{array}{l}\text { coverage of } \\
\text { agricultural } \\
\text { groups, \% }\end{array}$ & $\begin{array}{c}\text { area } \\
\text { coverage, } \\
\%\end{array}$ \\
\hline APK & 48,6 & 71,2 & 18,7 & 73,9 & 14 & 36,3 & 48,9 & 71,9 \\
\hline Вінницька & 38,9 & 83,7 & 23,6 & 89,5 & 29 & 35,1 & 55,5 & 77,1 \\
\hline Волинська & 58,6 & 97,6 & 14,3 & 85,1 & 44,1 & 91,1 & 52,1 & 93,9 \\
\hline Дніпропетровська & 49,1 & 90,2 & 16,2 & 90 & 19,6 & 33,1 & 60,1 & 82,4 \\
\hline Донецька & 66 & 95,8 & 18,7 & 93,1 & 20,6 & 86,3 & 69,5 & 95,1 \\
\hline Житомирська & 46,3 & 93,5 & 18,2 & 86,7 & 36,2 & 81,8 & 45,3 & 86,6 \\
\hline Закарпатська & 41,6 & 91,8 & 40,2 & 81,6 & 61,1 & 93,9 & 67,8 & 92,3 \\
\hline Зіпорізька & 74,3 & 96,8 & 32,2 & 88,4 & 19,4 & 78,5 & 65,8 & 90,8 \\
\hline Івано-Франківська & 55,2 & 81,3 & 14,6 & 58,7 & 48,2 & 68,8 & 56,5 & 70,1 \\
\hline Київська & 71,2 & 99,4 & 21 & 92,2 & 37,5 & 47,7 & 47 & 76,1 \\
\hline Кіровоградська & 63,4 & 99,1 & 28,4 & 94,7 & 34,8 & 71,4 & 66,4 & 98,9 \\
\hline Луганська & 28,5 & 61,9 & 4,7 & 46,9 & 31,2 & 46,7 & 48,4 & 69,6 \\
\hline Львівська & 61 & 90,9 & 13,9 & 77,9 & 41,7 & 62,8 & 54,1 & 70,7 \\
\hline Миколаївська & 57,7 & 98,1 & 16,7 & 87 & 11,3 & 50,6 & 59,1 & 89,7 \\
\hline
\end{tabular}




\begin{tabular}{|c|c|c|c|c|c|c|c|c|} 
Одеська & 49,8 & 92,3 & 16,7 & 72,9 & 12 & 26,3 & 43,9 & 68,9 \\
\hline Полтавська & 60,7 & 99,1 & 14,6 & 97,2 & 59,9 & 93,7 & 66,3 & 93,5 \\
\hline Рівненьска & 65,3 & 89,4 & 9,7 & 79,8 & 38,1 & 42,6 & 49,4 & 55,2 \\
\hline Сумська & 77,5 & 96 & 23,2 & 97,6 & 70,8 & 98,9 & 77,9 & 98,1 \\
\hline Тернопільська & 71,7 & 89,4 & 22,8 & 87,3 & 46,8 & 84,2 & 64,6 & 90,5 \\
\hline Харківська & 45,6 & 98,4 & 11,7 & 87,3 & 32,1 & 30,2 & 55,5 & 81,7 \\
\hline Херсонська & 75 & 99,7 & 20,2 & 90,3 & 19,4 & 88,6 & 73,3 & 99,1 \\
\hline Хмельницька & 67,1 & 90,9 & 27,3 & 83,6 & 44,4 & 59,5 & 49,1 & 72 \\
\hline Черкаська & 77,1 & 99,2 & 33,1 & 98,9 & 38,6 & 96,8 & 62,9 & 97,8 \\
\hline Чернівецька & 60,5 & 94,3 & 19,4 & 76,6 & 47,5 & 77 & 51,3 & 85,5 \\
\hline Чернігівська & 60,1 & 93,3 & 23,5 & 84,2 & 42,6 & 58,2 & 45,7 & 72 \\
\hline
\end{tabular}

In the context of agricultural land by arable land (histogram 1), we can conclude that the best result of the full coverage of areas for the appraisal indicators of agro-industrial groups of soils is such areas as Kiev 99.4\%, Poltava,

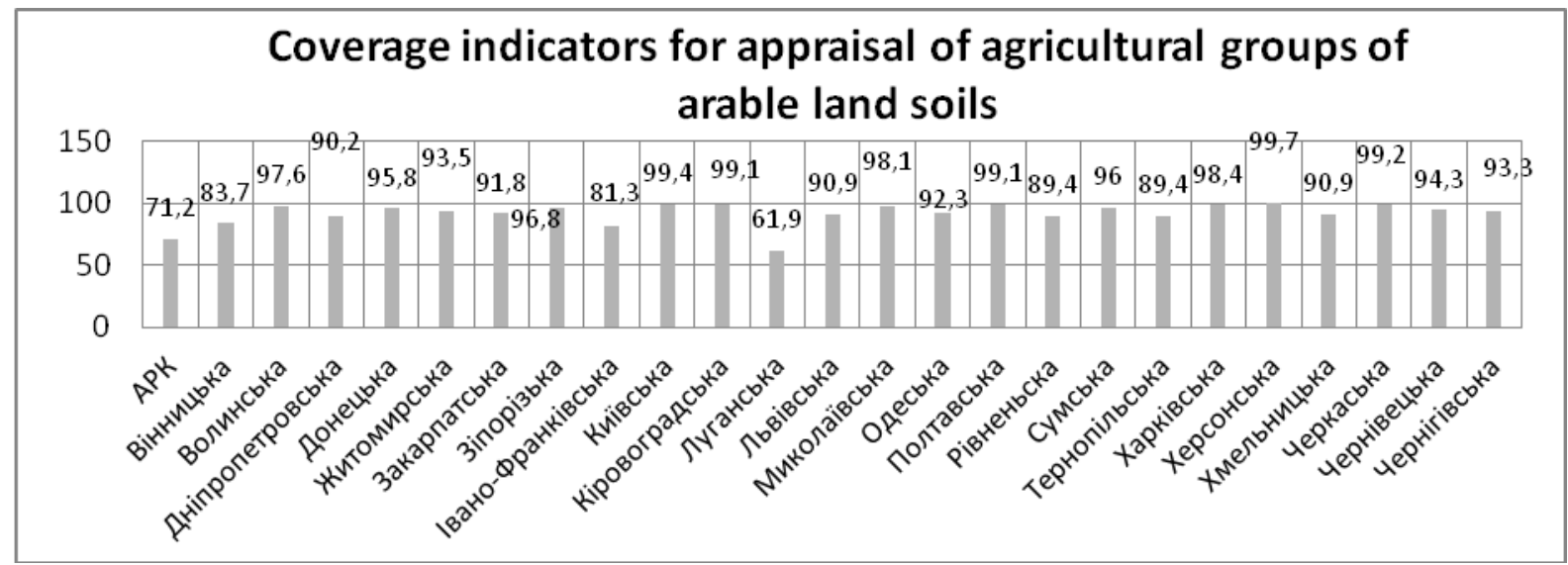

Kirovograd and Nikolaev regions at the level of $99.1 \%$, and the worst indicator among all analyzed regions in Lugansk is $61.9 \%$.

For perennial plantings (histogram 2) in Cherkasy 98.9\%, in Sumy 97.6\% and $94.7 \%$, in the Kirovograd region. The Lugansk Oblast is also the worst indicator among perennial plantations, which is at the level of $46.9 \%$, and among other regions, the average indicators of the coverage of areas according to the estimates of agricultural groups of soils are in the range 73. $-90 \%$. 


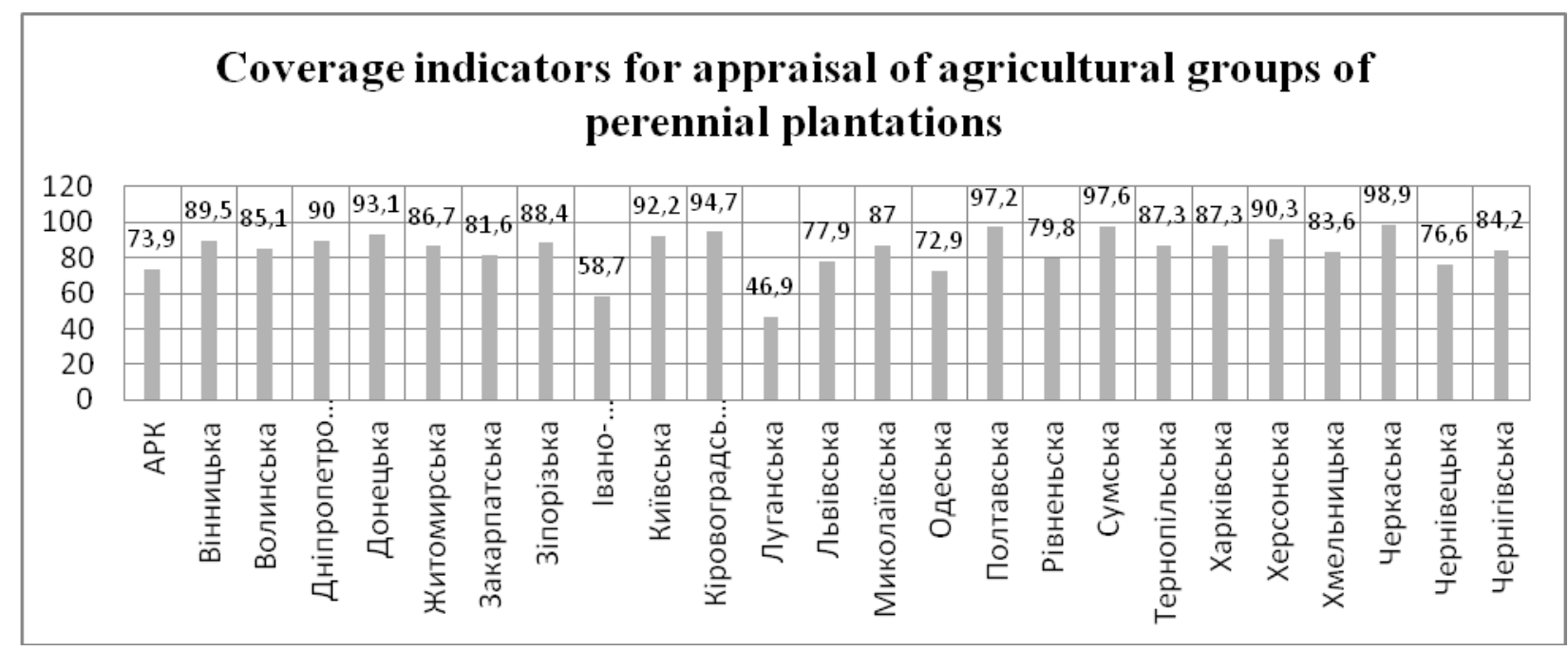

Among hayfields (histogram 3), the result of completeness of coverage of areas with indicators of agribusiness soil groups is the best in Cherkasskaya 98.9\%, Sumy $97.6 \%$ and Poltava 97.2\%, and on the bad side, Lugansk and IvanoFrankivsk oblasts with indicators $46.9 \%$ and $58.7 \%$ respectively.

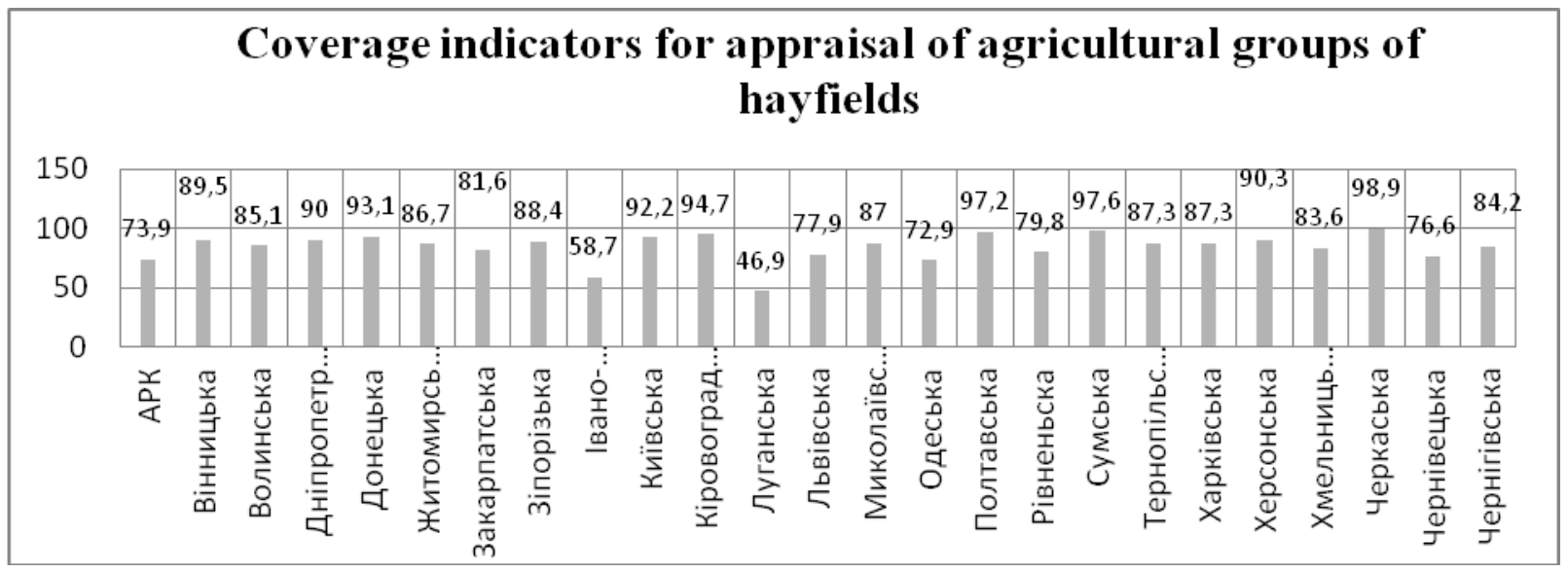

Coverage indicators for agro-industrial groups of pasture soils (histogram 4), the most secured estimated indicators of valuation are areas such as Kherson 99.1\%, Kirovograd 98.9\%, Sumy 98.1\%, and among areas in which indicators are at a slightly worse level, then we can distinguish Rivne $55.2 \%$.

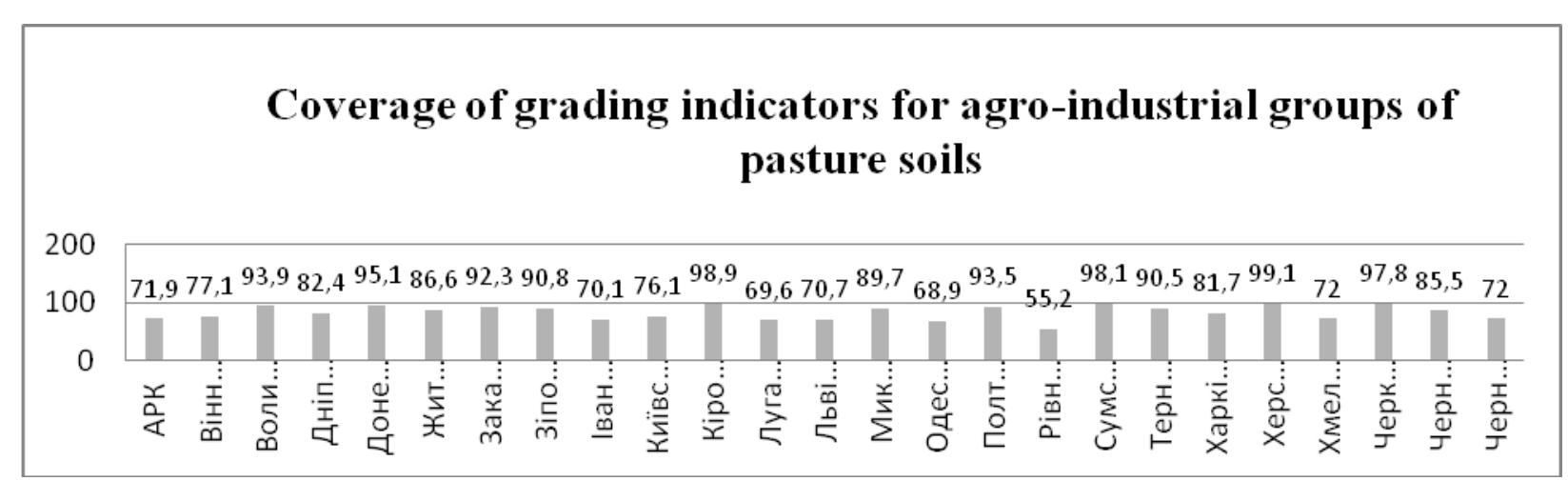


Based on the data analyzed, it can be concluded that the most secured estimated indicators of valuation are arable land, the indicator of which is at the level of $91.7 \%$, the coverage with estimated indicators of hayfields is $65.6 \%$, perennial plantings $84 \%$, pastures $83.2 \%$.

Conclusion. Taking into account the fact that the soil appraisal data is the basis for the economic valuation of agricultural land, and the data on the economic valuation of land is the basis for the normative monetary valuation of land plots, that is, there is a single, continuous methodological process of land valuation in which the data are unreliable in the first stage generates calculation errors in the following stages.

The study shows that the indicators of soil appraisal of 1993, by their completeness, far from always can serve as the basis for a continuous monetary assessment of agricultural land, which will require the development of approaches and algorithms for determining predictive indicators of soil appraisal for those agro-industrial groups of soils that are within certain territories, however, were not evaluated during the main soil appraisal work.

\section{References}

1- Zakon Ukrayiny “Pro otsinku zemel $\square$ ” vid 11.12.2003 № 1378IV. Available at: https://zakon.rada.gov.ua/laws/show/1378-15.

2- Mukha V. D., Kartamyshev N. I., Kochetov I. S., Mukha D. V.; pod red.

V. D. Mukhi. (1994). Agropochvovedeniye - M. : Kolos. - 528 p.

3- Gavrilyuk F. YA. (1974). Bonitirovka pochv. Izd. 2-ye, pererab. i dop. Ucheb. posobiye dlya vuzov. M., 272 p.

4- Medvedyev V.V., Plisko I.V. (2013) Propozytsiyi do vdoskonalennya chynnoyi metodyky bonituvannya hruntiv, Visnyk ahrarnoyi nauky. № 5. - p. 1418.

5- Martyn A.G. (2013). Onovlennya metodychnykh zasad normatyvnoyi hroshovoyi otsinky zemel $\square \quad$ sil $\square \mathrm{s} \square$ kohospodars $\square$ koho pryznachennya, Zemleustriy i kadastr, № 3, p. 30-51. 
6- Zakon Ukrayiny "Pro zemleustriy" vid 22.05.2003 № 858-IV. Available at: https://zakon.rada.gov.ua/laws/show/858-15.

7- Postanova Kabinetu Ministriv Ukrayiny «Pro ekspertnu hroshovu otsinku zemel $\square$ nykh dilyanok» vid 11.10.2003 № 1531. Available at: https://zakon.rada.gov.ua/laws/show/1531-2002-\%D0\%BF.

8- Postanova Kabinetu Ministriv Ukrayiny "Pro rozmiry ta Poryadok vyznachennya $\quad$ vtrat $\quad$ sil $\square \mathrm{s} \square$ kohospodars $\square$ koho $\quad$ i $\quad$ lisohospodars $\square$ koho vyrobnytstva, yaki pidlyahayut $\square$ vidshkoduvannyu” vid 17.11.1997 № 1279 . Available at: https://zakon.rada.gov.ua/laws/show/1279-97-\%D0\%BF.

9- Plisko I.V. (2019). Prostorovo-dyferentsiyovana systema upravlinnya yakistyu gruntiv (na prykladi rilli Ukrayiny). - Kvalifikatsiyna naukova pratsya na pravakh rukopysu. Dysertatsiya na zdobuttya naukovoho stupenya doktora nauk za spetsial $\square$ nistyu $\quad 06.01 .03 \quad$ "Ahrogruntoznavstvo i ahrofizyka» (Sil $\square \mathrm{s} \square$ kohospodars $\square$ ki nauky).- Natsional $\square$ nyy naukovyy tsentr «Instytut gruntoznavstva ta ahrokhimiyi imeni O.N. Sokolovs $\square$ koho», NAAN, Kharkiv 10- Tykhenko O.V. (2010). Porivnyal $\square$ nyy analiz metodiv bonituvannya hruntiv Ukrayiny. O.V. Tykhenko Visnyk Natsional $\square$ noho ahrarnoho universytetu.- №6. - P. 33-39.

11- Kanash O.P. (2008) Bonituvannya gruntiv: proponuyut $\square$ sya zminy, choho vony varti? O.P. Kanash Zemlevporyadnyy visnyk. - № 5.- 46-50.

12- Sunagatullina D.R. (2018). "Soil Boning and Its Impact on Cadastral Value." $\square$ Chelyabinsk: YuURSU, ASI-411, 88.

13- Makht V.A., Rudi V.A. (2016). Osnovy metodiki i sovremennyye problemy otsenki plodorodiya pochv dlya kadastrovoy otsenki sel'skokhozyaystvennykh ugodiy Vestnik Omskogo gosudarstvennogo agrarnogo universiteta.- №. 4 (24).

14- Bennet H.H. (1958). Osnovy okhrany pochv. - M.: Inostrannaya literature. 232. 


\section{Патиюк $А$.}

\section{АНАЛИЗ ПОЛНОТЫ ПОКАЗАТЕЛЕЙ БОНИТИРОВКИ ПОЧВ УКРАИНЫ НА ОСНОВЕ ФОНДОВЫХ МАТЕРИАЛОВ ИНСТИТУТА ЗЕМЛЕУСТРОЙСТВА УААН}

Принимая во внимание то, что данные бонитировки почв является основой проведения экономической оценки сельскохозяйственных угодий, данные по экономической оченке земель является основой при проведении нормативной денежной оценки земельных участков. То есть сущуествует единственный, непрерывный методологчческий прочеес оценки земель, в котором недостоверность данных в первом этапе порождает оиибки расчетов в следующих этапах.

Так как вопрос бонитировки почв в условиях рыночных земельных отношений не теряет актуальности, и принимая во внимание, что последний раз работы с бонитировки почв сельскохозяйственных земель в Украине были проведены ещуе в 1993 году, а за последние четверть века, формально, уже должны быть проведень, по крайней мере, три новых туры бонитировки почв, так как это прописано в Законе Украиньл «Об оценке земель», но фрактически же, показатели бонитировки почв, по разныл причинам, не обновлялись.

Авторам было проанализировано базу данных бонитировки почв Украины по шкалам 1993 года, а также экспликациями агропромышленных групп почв природно-сельскохозяйственных районов (ПСГР) за фондовыми материалами Института землеустройства УААН, на основе которых была осуществлена попьтка определить полноту охвата почвенного покрова ПСГР Украины показателям бонитировки.

Проведенное исследование показывает, что показатели бонитировки почв на основе фондовых материалов Института землеустройства УААН по своей полноте далеко не всегда могут выступать основой для сплошного проведения денежной и экспертной оценки земель сельскохозяйственного 
назначения и требуют проведения исследований используя новые подходы и наработки.

Ключевые слова: бонитет почв, экономическая оценка агропрочзводственные группь почв, оченка почв, сельскохозяйственные угодья.

\section{Патіюк 0 .}

АНАЛІЗ ПОВНОТИ ПОКАЗНИКІВ БОНІТУВАННЯ ІРУНТІВ УКРАЇНИ НА ОСНОВІ ФОНДОВИХ МАТЕРІАЛІВ ІНСТИТУТУ ЗЕМЛЕУСТРОЮ УААН

Беручи до уваги те, щзо дані бонітування грунтів є основою проведення економічної оцінки сільськогосподарських угідь, а дані з економічної оџінки земель є основою при проведенні нормативної громової оцінки земельних ділянок, тобто існує єдиний, безперервний методологічний процес оцінки земель, в якому недостовірність даних в пермому етапі породжує помилки розрахунків в наступних етапах.

Так як питання бонітування трунтів в умовах ринкових земельних відносин не втрачає актуальності, та беручи до уваги, щзо востаннє роботи з бонітування грунтів сільськогосподарських земель в Україні були проведені щуе у 1993 рочуі, а за останні чверть сторіччя, формально, вже мали б бути проведені, принаймні, три нових тури бонітування грунтів, так як изе прописано в Законі України «Про оцінку земель»,але фактично ж, показники бонітування грунтів, з різних причин, не оновлювалися.

Автором було проаналізовано базу даних бонітування грунтів Украӥни за шкалами 1993 року, а також експлікаціями агровиробничих груп грунтів природно-сільськогосподарських районів (ПСГР) за фондовими матеріалами Інституту землеустрою УААН, на основі яких була здійснена спроба визначити повноту охоплення грунтового покриву ПСГР Украӥни показниками бонітування.

Проведене дослідження показало, щуо показники бонітування трунтів на основі фрондових матеріалів Інституту землеустрою УААН за своєю 
повнотою далеко не завжди можуть виступати основою для суцільного проведення нормативної та експертної грошової оичінки земель сільськогосподарського призначення $i$ потребують проведення подальших досліджень використовуючи нові підходи та напрацуювання.

Ключові слова: бонітет грунтів ,економічна оцінка агровиробничі групи грунтів, оцінка грунтів, сільськогосподарські угіддя. 